\title{
Is Mar del Plata (Argentina) a sustainable city? An evaluation of the sustainability of urban and peri-urban areas using indicators
}

\author{
Mar del Plata (Argentina) é uma cidade sustentável? \\ Avaliação da sustentabilidade das áreas urbanas e \\ periurbanas usando indicadores
}

Laura Zulaica

National Council of Scientific and Technical Research (CONICET), Institute of Habitat and Environment (IHAM), Faculty of Architecture, Urbanism and Design (FAUD), National University of Mar del Plata (UNMdP), PhD. in Geography, Mar del Plata, Buenos Aires Province, Argentine. E-mail: laurazulaica@yahoo.com.ar

doi:10.18472/SustDeb.v10n2.2019.20646

Received: 17/12/2018

Accepted: 25/07/2019

ARTICLE - VARIA

\begin{abstract}
The urbanization process in Latin America has reached unprecedented levels. The need to mitigate its effects and improve cities sustainability has become a pressing challenge. In this context, the assessment of sustainability acquires an increased recognition as a diagnosis tool to advance towards the ecological, social, economic and political objectives of sustainable development. On the basis of previous studies, this paper is intended to comparatively evaluate the urban and environmental sustainability of Mar del Plata city (Argentina) and its peri-urban area. A Sustainability Index (SI) was built. The most favourable SI values were generally found in the urban area, while the most critical ones were identified in the peri-urban area. The incidence of the topics in the $\mathrm{Sl}$, reveals differences between the urban and peri-urban areas. The outcome is expected to strengthen policy integration for present and future generations leading to the Sustainable Development Goals at a local scale.
\end{abstract}

Keywords: Sustainability indices and indicators; Environmental and urban sustainability; Spatial analysis; Sustainable Development Goals; Management of urban and peri-urban areas.

\section{RESUMO}

O processo de urbanização na América Latina atingiu níveis sem precedentes. A necessidade de mitigar seus efeitos e melhorar a sustentabilidade das cidades tornou-se um desafio premente. Nesse contexto, a avaliação da sustentabilidade adquire um reconhecimento crescente como ferramenta diagnóstica para avançar em direção aos objetivos ecológicos, sociais, econômicos e políticos do desenvolvimento sustentável. Com base em estudos anteriores, este artigo pretende avaliar comparativamente a sustentabilidade urbana e ambiental da cidade de Mar del Plata (Argentina) e sua área peri-urbana. Um Indicador de Sustentabilidade (IS) foi construído. Os valores de IS mais favoráveis foram geralmente encontrados na área urbana, enquanto os mais críticos foram identificados na área peri-urbana. A incidência dos tópicos no IS revela diferenças entre as áreas urbanas e periurbanas. Espera-se que os resultados obtidos fortaleçam a integração de políticas para as gerações atuais e futuras, levando os Objetivos de Desenvolvimento Sustentável à escala local. 
Palavras-chave: Índices e indicadores de sustentabilidade; Sustentabilidade ambiental e urbana; Análise espacial; Objetivos de Desenvolvimento Sustentável; Gestão de áreas urbanas e periurbanas.

\section{INTRODUCTION}

The urbanization process has reached an unprecedented level worldwide. As a consequence, countries around the world have designed various schemes to mitigate the effects of the process and improve the sustainability of urbanization (ZHOU et al., 2015).

The population living in megacities increased from 39 million in 1970 to 359 million in 2011 (UNITED NATIONS, 2012).

Latin America and the Caribbean is the second-most urbanized region in the planet with $80 \%$ of its population living in cities. The percentage of urban population in the region increased from $44 \%$ to $78 \%$ from 1960 to 2015; and such a high urbanization rate has promoted the growth of a new type of cities: emerging and intermediate-sized cities, with populations ranging from 100,000 to 2,000,000 inhabitants (INTER-AMERICAN DEVELOPMENT BANK, 2016).

The rapid and accelerated urbanization of intermediate cities has created numerous social and environmental problems exacerbated by the lack of adequate planning. In this context, Latin American cities, in general, and Argentine cities, in particular, face major challenges to achieve sustainable development objectives.

Current urban growth trends combine simultaneous processes of attraction and expansion, which are expressed in the territorial configuration by a high degree of dispersion and low occupancy density that generate impacts on the urban periphery and rural areas (ROCCA et al., 2014).

Conceptually, sustainable development seeks to strike a balance between the needs of current and future generations. Ever since the Report of the Brundtland Commission (WORLD COMMISSION ON ENVIRONMENT AND DEVELOPMENT, 1987), countries have begun to define objectives and priorities in order to materialize such development, considering national needs and aspirations.

Despite being an internationally accepted and disseminated concept, the most critical lines of thought indicate that sustainable development shows remarkable versatility and ambiguity (REBORATTI, 2000; GALLOPIN, 2003). As a consequence, it is difficult to analyse specific situations and design intervention policies.

Several authors have made an effort to synthesize the characteristics of sustainable development in order to overcome these limitations and considered different dimensions that can be summarized as follows: ecological, economic, socio-cultural, and political (GUIMARÃES, 2003; MORI and CHRISTODOULOU, 2012; BRAULIO-GONZALO et al., 2015).

In an urban context, Tran (2016) defines sustainable urban development as a process of synergetic integration, interaction and co-evolution among the economic, social, physical and environmental subsystems that make up a city, so as to guarantee the well-being of the population in the long term, while maintaining a balance with the surrounding areas and contributing to reduce the harmful effects on the biosphere.

These achievements are reflected in the 17 Sustainable Development Goals (SDGs), defined in the United Nations Sustainable Development Summit held in 2015. At that Summit, the United Nations member states approved the 2030 Agenda for the Sustainable Development which aims at ending poverty, fighting inequality and injustice and fixing climate change. These objectives are the most pressing challenges of our time (WOOD et al., 2018). Understanding their interactions can provide key insights to prioritize effective and efficient policy options. 
In response to the current reality of intermediate cities in Latin America and the Caribbean, the InterAmerican Development Bank (IDB) launched in 2011 the Emerging and Sustainable Cities Initiative $(\mathrm{ESCl})$. Even though the concept of a sustainable city can be approached from different perspectives, the aforementioned initiative defines a sustainable city as a city that offers its citizens good quality of life, minimizes its impact on the natural environment, and has sufficient fiscal and administrative capacity to carry out its urban functions with citizen participation.

Based on the above, the IDB (2014) argues that, in order to achieve a sustainable city, three pillars should be analysed: (i) environmental and climate change sustainability, (ii) urban sustainability, and (iii) governance and fiscal sustainability. To measure the progress and setbacks of cities towards these objectives, the IDB uses sustainability indicators. As Reed et al. (2006) set out, these indicators are not only useful to measure progress, but also to discover problems, establish sustainable development objectives and identify appropriate management strategies.

Mar del Plata city, located in the General Pueyrredon district, Argentina, faces the challenge of meeting its sustainability goals. Excluding the districts comprising the Metropolitan Region of Buenos Aires, Mar del Plata ranks second in demographic importance in the province of Buenos Aires. Its urban expansion has reached a building footprint (area utilised by construction) of 22,084 ha (GAREIS and FERRARO 2015). According to the last intercensal period (2001-2010), the demographic growth rate of the district was $9.7 \%$ and the total registered population was 618,989 residents (INSTITUTO NACIONAL DE ESTADÍSTICAS Y CENSOS, 2010).

Mar del Plata has a peri-urban area of approximately 35,000 ha, defined and characterized in previous studies (RODRÍGUEZ IGLESIAS and BAZÁN, 2009; ZULAICA and FERRARO, 2016; among others). As highlighted in the cited studies, there are numerous problems that characterize the peri-urban area, such as the incompatibility of land uses, social inequality, exposure to risk situations, difficulties in accessing infrastructure and urban services and segregation processes. Figure 1 illustrates the location of the city and the spatial delimitation of its urban and peri-urban areas.
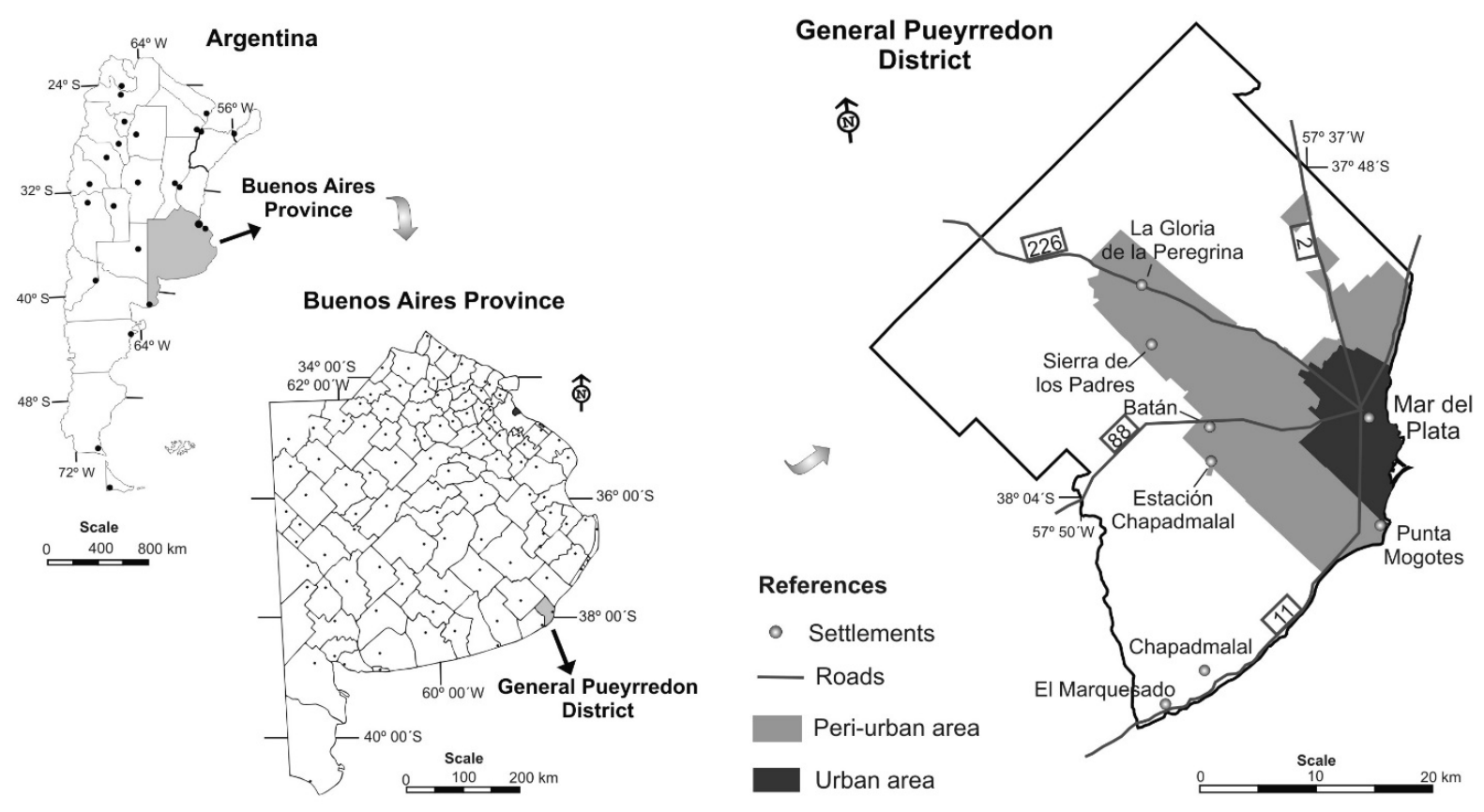

Source: Self elaboration based on Zulaica and Ferraro (2016).

Figure 1 | General Pueyrredon district: Location of the urban and peri-urban areas of Mar del Plata. 
The social and environmental issues that affect the city and, especially, its expanding areas, distance Mar del Plata from the sustainability goals. In the framework of the ESCI, Mar del Plata city was chosen in March 2012 to participate in the Program. The application of the methodology proposed by ESCI during 2012 provided an updated and comprehensive diagnosis of the problems that affect the city environmental, urban and fiscal sustainability (Municipio de General Pueyrredon 2013). However, little has been done to deepen the distinctions within the city and its peri-urban territory in the light of the indicators considered. Recent research conducted in urban and peri-urban areas has addressed this topic in different countries (MICHAEL et al., 2014; BRAULIO-GONZALO et al., 2015; ZHOU et al., 2015). However, few of them explore Latin American contexts.

On the basis of the dimensions proposed by ESCl and in order to analyse the current state of the city, performance indicators were grouped according to topics of interest for local management. The evaluation of public management performance lies at the heart of decision-makers in the different levels of management (national, regional and local). According to Bonnefoy and Armijo (2005), performance indicators provide public officers with information on key areas of action such as efficiency, effectiveness, quality, and resource economics.

Considering the above, this work is intended to assess the urban and environmental sustainability of Mar del Plata city and its peri-urban area, making comparisons. For this purpose, a synthetic index was built taking as reference the topics (categories) and indicators proposed in $\mathrm{ESCl}$. The comparative analysis acquires a particular interest given that numerous aspects related to the concept of sustainability express situations of conflictivity in the peri-urban area of Mar de Plata. In addition, the study of cities as a whole often fails to show the problems and the complexity existing in the peri-urban spaces. Hence the importance of establishing differentiations. The outcome is expected to strengthen policy integration for present and future generations leading to the Sustainable Development Goals at a local scale.

\section{METHODOLOGY}

The methodology used attempts to integrate some of the dimensions contained in the concept of sustainability and redefined by the IDB (2014). In this study, emphasis is placed on the urban and environmental dimensions. As a result, a synthesized index, called the Sustainability Index (SI), was created from the integration of an Urban Sustainability Index, composed of 19 indicators grouped into 8 topics and an Environmental Sustainability Index, defined by 13 indicators also grouped into 8 topics.

The purpose of $\mathrm{SI}$ is to evaluate objective aspects of urban and environmental sustainability based on quantitative indicators. The methodology used relies on previous research works but is mainly in line with that applied by Tomadoni et al. (2014) and Tomadoni and Zulaica (2015). Some data on this subject matter were provided by Tomadoni and Zulaica (2016) and Zulaica and Tomadoni (2016). The employed methodology follows this sequence: selection and standardization of indicators, construction of a synthetic index, comparative analysis of the special distribution of the results. The spatial reference units of this study are the census radii of 2010 (INSTITUTO NACIONAL DE ESTADÍSTICAS Y CENSOS, 2010). Unfortunately, only disaggregated information is available in those space units.

\subsection{SELECTING INDICATORS}

According to Agol et al. (2014), indicators selection is often subjective, and is dependent, in general, on factors such as cost-effectiveness, ease of understanding, reliability and comparability.

In this case, the indicators selected that reflect the environmental dimension of sustainability comprise the following topics: water provision, sanitation and drainage, energy, solid waste disposal, air quality, greenhouse gas emissions, noise and vulnerability to natural disasters. Regarding the urban dimension, it encompasses the following topics: land management/land use, urban inequality, transportation and mobility, employment, connectivity, education, public safety and health. 
The nomenclature of the categories considered and the integrated indicators in each of them were adjusted according to the information available and that could be disaggregated in the census radii. Most indicators were obtained from the last national census (INSTITUTO NACIONAL DE ESTADÍSTICAS Y CENSOS, 2010), using the REDATAM software ( + SP Process). In some cases we used other sources of information: Sabuda (2008); Ferraro et al. (2013); Municipio de General Pueyrredon (2013); Mar del Plata Entre Todos initiative (2016). The list of topics, indicators and information sources by dimensions is summarized in Table 1.

Table 1 | Topics, indicators and sources of information.

\begin{tabular}{|c|c|c|c|}
\hline & Topics & Indicators & Source of Information \\
\hline \multirow{12}{*}{ 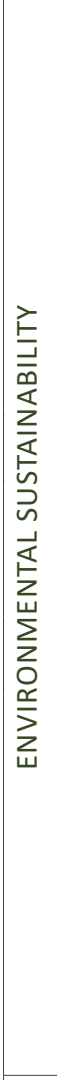 } & \multirow[t]{2}{*}{ WATER PROVISION } & \begin{tabular}{|c|}
$\begin{array}{c}\text { Percentage of households with public water supply } \\
\text { coverage }\end{array}$ \\
$\begin{array}{c}\text { Percentage of households without piped water into } \\
\text { dwelling }\end{array}$ \\
\end{tabular} & $\begin{array}{c}\text { INSTITUTO NACIONAL DE } \\
\text { ESTADÍSTICAS Y CENSOS, INDEC } \\
(2010)\end{array}$ \\
\hline & & Annual water consumption per capita & $\begin{array}{l}\text { Own data obtained from Municipio } \\
\text { de General Pueyrredon (2013). }\end{array}$ \\
\hline & \multirow{2}{*}{$\begin{array}{l}\text { SANITATION AND } \\
\text { DRAINAGE }\end{array}$} & $\begin{array}{c}\text { Percentage of households with home connection to } \\
\text { the sewerage services }\end{array}$ & \multirow{2}{*}{ INDEC (2010) } \\
\hline & & $\begin{array}{l}\text { Percentage of households with sanitary installations } \\
\text { with water discharge }\end{array}$ & \\
\hline & WASTE & Amount of waste generated & $\begin{array}{l}\text { Own data obtained from Municipio } \\
\text { de General Pueyrredon (2013). }\end{array}$ \\
\hline & ENERGY & Percentage of households with gas network supply & INDEC (2010) \\
\hline & AIR QUALITY & $\begin{array}{l}\text { Percentage of radius surface located less than } 300 \\
\text { m away from pollution sources }\end{array}$ & $\begin{array}{l}\text { Own data obtained from Municipio } \\
\text { de General Pueyrredon (2013). }\end{array}$ \\
\hline & $\begin{array}{l}\text { MITIGATION OF } \\
\text { CLIMATE CHANGE }\end{array}$ & $\begin{array}{c}\text { Generated greenhouse gas emissions (CO2) in tons } \\
\text { adjusted to energy consumption }\end{array}$ & $\begin{array}{l}\text { Own data obtained from Ferraro et } \\
\text { al. (2013). }\end{array}$ \\
\hline & NOISE POLLUTION & $\begin{array}{l}\text { Percentage of radius surface located less than } 300 \\
\text { m away from noise pollution }\end{array}$ & $\begin{array}{l}\text { Own data obtained from Municipio } \\
\text { de General Pueyrredon (2013). }\end{array}$ \\
\hline & \multirow{3}{*}{$\begin{array}{l}\text { VULNERABILITY } \\
\text { TO NATURAL } \\
\text { DISASTERS }\end{array}$} & Percentage of radius surface vulnerable to flooding & $\begin{array}{l}\text { Own data obtained from Mar del } \\
\text { Plata Entre Todos initiative (2016). }\end{array}$ \\
\hline & & $\begin{array}{c}\text { Percentage of areas where activities that imply } \\
\text { environmental risks are developed or placed at } 300 \\
m \text { of those areas }\end{array}$ & $\begin{array}{l}\text { Own data obtained from Municipio } \\
\text { de General Pueyrredon (2013) and } \\
\text { surveys. }\end{array}$ \\
\hline & & Percentage of radius surface occupied by slums & $\begin{array}{l}\text { Own data obtained from Mar del } \\
\text { Plata Entre Todos initiative (2016) } \\
\text { and surveys. }\end{array}$ \\
\hline \multirow{8}{*}{ 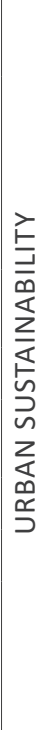 } & \multirow{8}{*}{$\begin{array}{l}\text { LAND } \\
\text { MANAGEMENT }\end{array}$} & Population density & $\begin{array}{l}\text { Own data obtained from INDEC } \\
(2010) .\end{array}$ \\
\hline & & Percentage of substandard homes & \multirow{6}{*}{ INDEC (2010) } \\
\hline & & \begin{tabular}{|c|} 
Percentage of households with severe overcrowding \\
(more than three persons per room)
\end{tabular} & \\
\hline & & Percentage of occupied private homes & \\
\hline & & $\begin{array}{c}\text { Percentage of households with exclusive use } \\
\text { bathroom }\end{array}$ & \\
\hline & & Percentage of households without a refrigerator & \\
\hline & & Percentage of households without a computer & \\
\hline & & $\begin{array}{l}\text { Green space surfaces with respect to population in } \\
\text { the radius }\end{array}$ & $\begin{array}{c}\text { Own data obtained from } \\
\text { Municipio de General Pueyrredon } \\
\text { (2013) and Mar del Plata Entre } \\
\text { Todos initiative (2016). }\end{array}$ \\
\hline
\end{tabular}




\begin{tabular}{|c|c|c|c|}
\hline \multirow{11}{*}{ 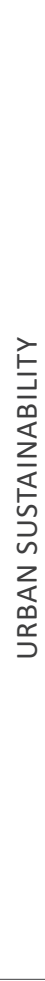 } & $\begin{array}{l}\text { URBAN } \\
\text { INEQUALITY }\end{array}$ & $\begin{array}{l}\text { Percentage of households with at least one } \\
\text { indicator of unsatisfied basic needs }\end{array}$ & INDEC (2010) \\
\hline & $\begin{array}{l}\text { TRANSPORTATION } \\
\text { AND MOBILITY }\end{array}$ & $\begin{array}{l}\text { Percentage of radius surface area with public } \\
\text { transport service coverage less than } 300 \text { meters }\end{array}$ & $\begin{array}{c}\text { Own data obtained from } \\
\text { Municipio de General Pueyrredon } \\
\text { (2013) and surveys. }\end{array}$ \\
\hline & \multirow{2}{*}{ EMPLOYMENT } & Potential dependence index & \multirow{2}{*}{ INDEC (2010) } \\
\hline & & Unemployment rate & \\
\hline & CONNECTIVITY & $\begin{array}{l}\text { Percentage of population with a cell phone in the } \\
\text { home }\end{array}$ & INDEC (2010) \\
\hline & \multirow{4}{*}{ EDUCATION } & Literacy rate & \multirow[b]{2}{*}{ INDEC (2010) } \\
\hline & & $\begin{array}{c}\text { Percentage of population aged } 3 \text { years or more with } \\
\text { a computer in their home }\end{array}$ & \\
\hline & & $\begin{array}{l}\text { Percentage of radius surface within } 500 \text { meters of } \\
\text { an educational facility }\end{array}$ & $\begin{array}{c}\text { Own data obtained from } \\
\text { Municipio de General Pueyrredon } \\
\text { (2013), Sabuda (2008) and } \\
\text { surveys. }\end{array}$ \\
\hline & & $\begin{array}{l}\text { Percentage of population aged } 18 \text { years or more } \\
\text { that attends or attended college or university }\end{array}$ & INDEC (2010) \\
\hline & CITIZEN SECURITY & $\begin{array}{l}\text { Percentage of intentional homicides with respect to } \\
\text { the total registered in the district }\end{array}$ & $\begin{array}{c}\text { Own data obtained from } \\
\text { Municipio de General Pueyrredon } \\
\text { (2013). }\end{array}$ \\
\hline & HEALTH CARE & $\begin{array}{l}\text { Percentage of radius surface less than } 500 \text { meters } \\
\text { away from a public health centre. }\end{array}$ & $\begin{array}{c}\text { Own data obtained from } \\
\text { Municipio de General Pueyrredon } \\
\text { (2013) and surveys. }\end{array}$ \\
\hline
\end{tabular}

Source: Prepared by the authors on the basis of data supplied by Tomadoni et al. (2014) and Zulaica and Tomadoni (2015).

\subsection{STANDARDIZATION OF INDICATORS}

After obtaining the values for the different indicators selected, they were standardized to be transformed into dimensionless units for comparisons purposes. In this case, the Omega Score technique was used (BUZAI, 2003).

This procedure transforms indicators data into a measuring range that runs from 0 (worst situation) to 1 (best situation). These values correspond to the minimum and maximum data, respectively.

Then a correlations matrix was built for each topic comprising more than two indicators. Said matrix contained the results obtained from the application of the Pearson correlation coefficient or Pearson's $r$ (PEARSON, 1895) among the different indicators corresponding to the topic. This procedure was applied to determine strong associations between indicators and to detect redundancy (PÉREZ MORALES et al., 2016).

Maximum correlations were identified and "reciprocal pairs" were obtained for each topic, which define composite indicators. The formulas used for standardization are shown below according to their positive or negative sense:

- Indicators whose increase implies a worse relative situation:

$$
S V=(H-d) /(H-I)
$$

- Indicators whose increase implies a better relative situation:

$$
S V=[1-(H-d) /(H-I)]
$$

Where: SV: standardized indicator value/composite indicator; $d$ : original data to be standardized; $H$ : highest indicator value/composite indicator; $m$ : lowest indicator value/composite indicator.

In the case of composite indicators, the standardized value was calculated from the average of the standardized scores of the two indicators contained in the reciprocal pair. Then, the two dimensions were weighted to achieve a total score of 1 , allocating 0.5 points to each one. The indicators and the composite indicators were weighted with respect to that total score, assuming a relatively equitable distribution among the topics. 


\subsection{CONSTRUCTION OF THE SUSTAINABILITY INDEX (SI)}

The Sustainability Index (SI) resulted from the previous construction of an Urban Sustainability Index (USI) and an Environmental Sustainability Index (ESI), whose maximum value (best condition) was 0.5 in each case. The USE and the ESI are obtained from the sum of the standardized values of the indicators included in the themes that make up each dimension (TOMADONI and ZULAICA, 2016). The sum of the results obtained for both dimensions expresses the value of the SI in the spatial unit.

Once the standardized values of the composite indicators/indicators were calculated, the results obtained in each radius by dimension were added, defining the $\mathrm{SI}$, which is expressed as follows:

$$
\mathrm{SI}=\Sigma S V U S+\Sigma S V E S
$$

Where: SVSU: standardized value of the Urban Sustainability indicators; and SVES: standardized value of the Environmental Sustainability indicators.

\subsection{COMPARATIVE ANALYSIS OF SPATIAL DISTRIBUTION}

The results obtained for each topic were spatially represented in maps designed using gvSIG software, version 1.11.

Integrating results in an index allowed to differentiate five categories for each of the dimensions and for the final index. They reflected the favourable, intermediate and unfavourable situations (sustainability: very low, low, medium, high and very high).

The spatial configuration was obtained in all cases with the natural breaks classification method. This method identifies breaks between classes using a statistical formula (Jenks optimization), which minimizes each class's mean deviation from the class mean. Afterwards, comparisons were established in the results obtained in both dimensions for the urban and peri-urban area of Mar del Plata.

Finally, the topics that had the greatest bearing on environmental and urban sustainability were determined. To do so, the linear correlation coefficients were calculated. As mentioned above, this coefficient measures the degree of linear association between two quantitative variables.

\section{RESULTS AND DISCUSSION}

The results obtained are presented in four sections. The first section refers to the preliminary results obtained from the standardization of the indicators by topics. This allows to conduct comparisons between urban and peri-urban areas. The second section presents the results of the indices built and provides an analysis of their spatial distribution in the urban and peri-urban areas. Then the topics with the greatest impact on the distribution of the index are identified and discussed and, finally, the fourth section, reflects on the importance of assessing the sustainability of cities, especially in urban areas.

\subsection{SUSTAINABILITY TOPICS IN THE URBAN AND PERI-URBAN AREAS OF MAR DEL PLATA}

The conformation of peri-urban areas is highly dynamic and is due to growth processes sustained in economic and political phenomena. The absence of urban planning that directs growth processes explains the loss of well-being of its inhabitants and the manifestation of territorial problems: difficulties in accessing infrastructure and services; waste and emission pollution; resource degradation and exposure to environmental hazards, among others. These problems restrict the scope of the objectives of urban and environmental sustainability. 
Out of the 13 indicators selected for the environmental dimension of sustainability, 2 composite indicators were defined, and of the 19 indicators for the urban dimension, 3 composite indicators were defined through the construction of a correlation matrix. Composite indicators are simplified representations that seek to summarize a multidimensional concept in a simple (one-dimensional) index based on a conceptual model (SCHUSCHNY and SOTO, 2009).

When the standardized mean values are compared based on the topics corresponding to the two dimensions, greater contrast is found within the urban dimension (Figure 2). However, when comparing urban and peri-urban areas, the most significant differences are noticed in the environmental dimension (Figure 3 ). The most favorable situations reach 1 or values close to 1 , while the unfavorable ones register 0 or approach that value.

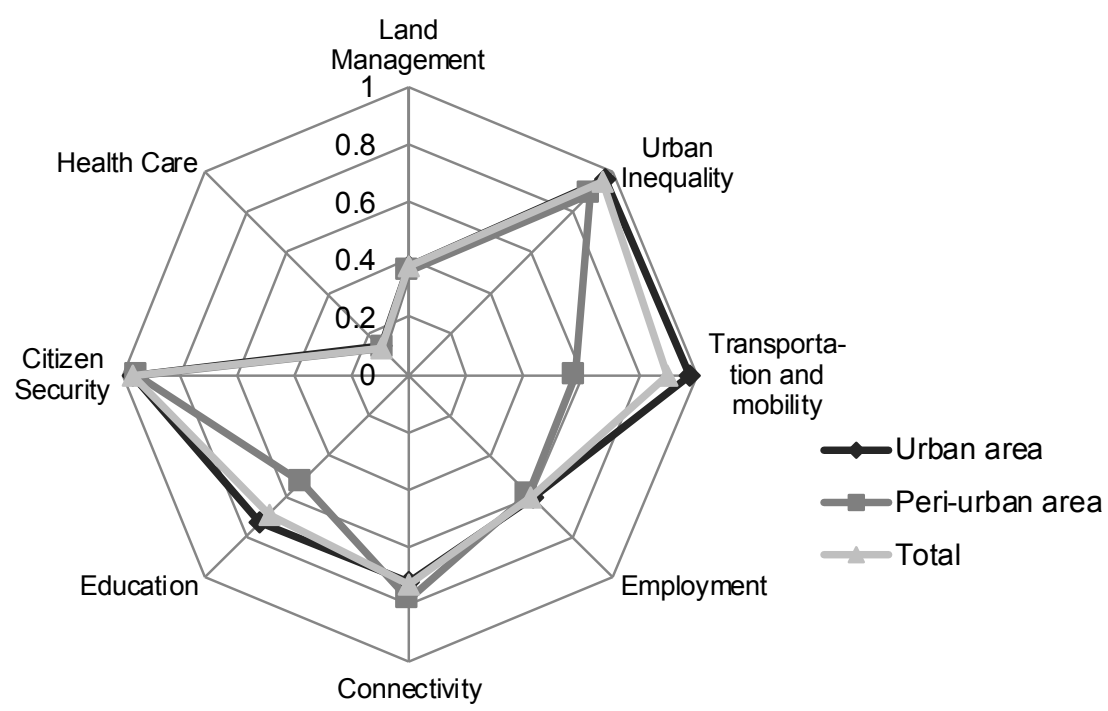

Figure 2 | Urban Sustainability: Radar chart of the standardized mean values by topics.

Source: Self elaboration based on standardized values.

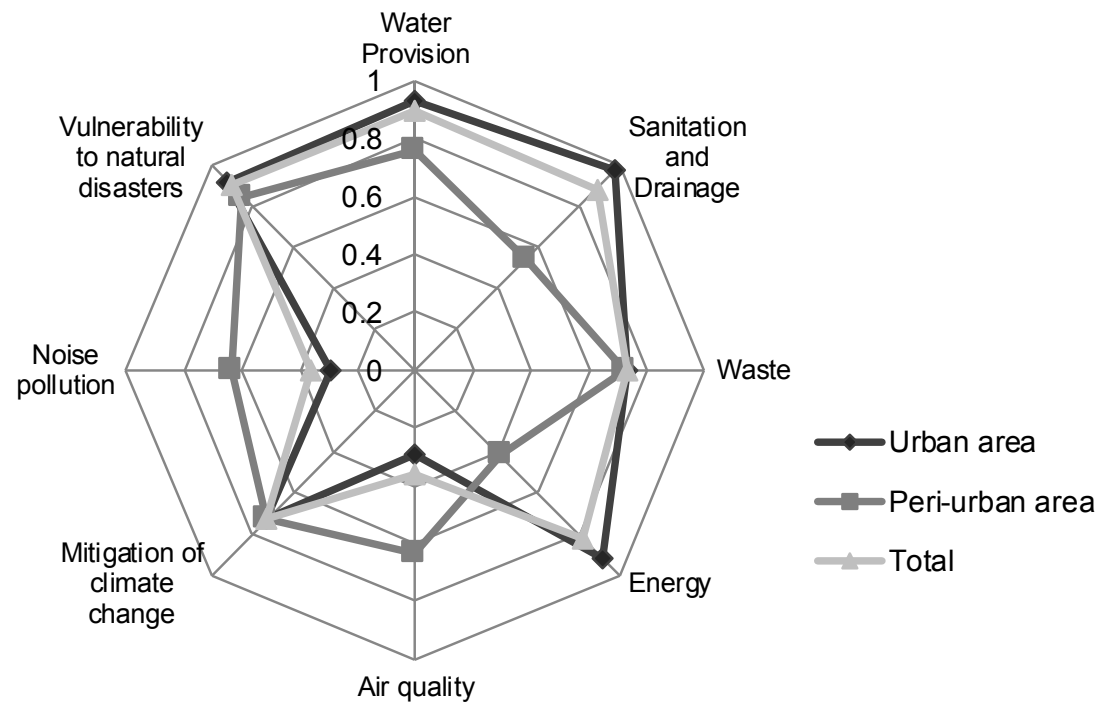

Figure 3 | Environmental sustainability: Radar chart of the standardized mean values by topics.

Source: Self elaboration based on standardized values. 
Regarding the environmental dimension, the peri-urban area as a whole accounts for more unfavourable values in 6 out of the 8 topics that make up the dimension. This difference is more evident in the water provision, sanitation and drainage, and vulnerability to natural disasters topics.

The analysis of the indicators grouped into the water provision topic allowed us to affirm that the water network coverage is adequate in Mar del Plata city, but not in the peri-urban areas. Something similar occurs with the indicator of households without piped water into dwellings. Differences are more pronounced between urban and peri-urban areas in the case of sanitation and drainage. Regarding this topic, the number of homes with connection to the sewerage services sets out the most significant difference. As far as energy is concerned, gas network supply differs significantly between urban and peri-urban areas, the situation in the latter being clearly more critical.

The vulnerability to natural disasters topic in the peri-urban area shows more unfavourable conditions associated mainly with the exposed population living in informal settlements and with the development of activities that involve exposure to environmental risks (predominantly rural).

The indicators related to solid waste and climate change mitigation do not show relevant differences. The opposite occurs with air quality and noise pollution whose standardized values in the urban area are lower. The presence of green and open spaces in the peri-urban would explain such a better condition.

As regards the urban dimension, access to public health care services is not much conditioned by distance in all cases, regardless of whether urban or peri-urban areas are analysed. Something similar occurs with land management/land use, which includes housing- and land use- related indicators.

Urban inequality shows greater contrasts in the peri-urban area, where more significant social differences coexist. Employment is also slightly more unfavourable in the peri-urban area, along with connectivity and citizen security.

Commuting by public transportation is more favourable in the urban area where the service is offered with a wider range and scope. Education also plays a part in social sustainability since it is considered a key pathway for personal development and to ensure employability. This topic is more critical in the peri-urban area, an outcome in line with the results obtained for employment.

\subsection{SUSTAINABILITY INDEX}

The indices developed in the framework of this work for the urban and peri-urban areas of Mar del Plata city (ESI, USI, and SI) are a key tool for monitoring long-term sustainability trends from a retrospective perspective. The information provided contributes to short-term projections and to optimize decisions for the future.

As already mentioned, working with a large number of indicators was difficult in terms of practicality (TRAN, 2016). When creating the indices, the lack of weights for the different topics and indicators that define sustainability became a constraint (KWATRA et al., 2016), since there are topics with a greater number of variables and/or that have a particular interest.

Weighting the topics and indicators allows to highlight the differences between the spatial units within the urban and peri-urban areas. In this study, we chose to weight topics and indicators based on the comparative analysis carried out for the different topics. In this sense, regarding the environmental dimension, the highest values were given to water provision, sanitation and drainage and vulnerability to natural disasters (Figure 4). This decision was based on the number of composite indicators/ indicators that make up the topics as well as on the significance of the contrasts expressed by these topics between urban and peri-urban areas. On the other hand, this dimension encompasses essential basic services (drinking water and sewage), whose lack of supply is a threat to vulnerable populations and increases environmental risk (NATENZON, 1998). 


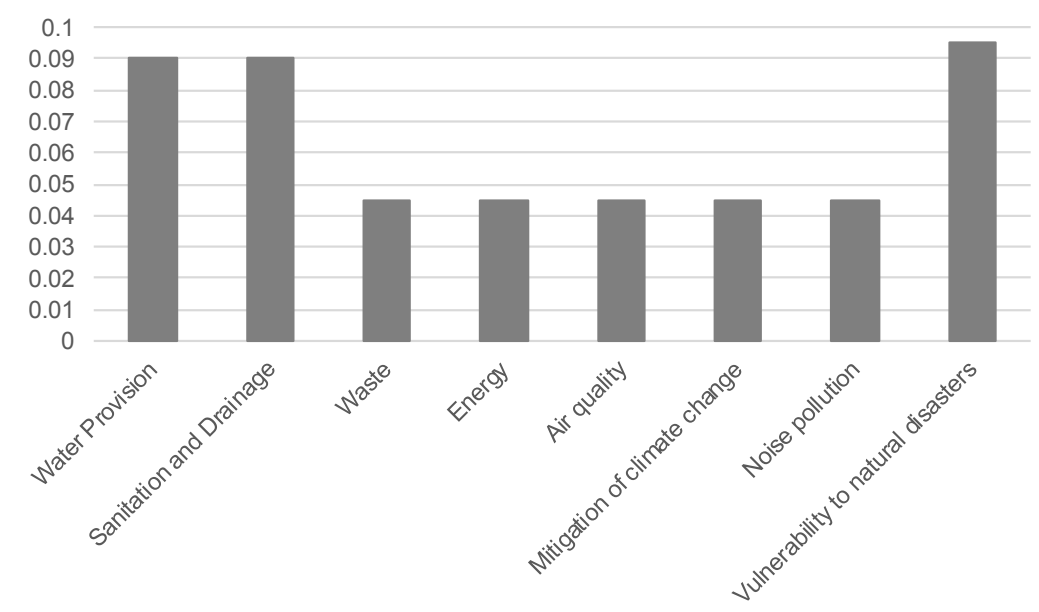

Figure 4 | Environmental sustainability: Weighting values of the topics considered in the index development.

Source: Self elaboration based on previous studies (ZULAICA and TOMADONI, 2015; TOMADONI and ZULAICA, 2016).

With regard to the urban dimension, the land management/land use topic also includes several indicators with critical values. These indicators generally reflect housing conditions strongly linked to the vulnerability found in the environmental dimension. Additionally, education affects work opportunities, a necessary means for access to goods and services. As a consequence, the aforementioned topics received the highest weights (Figure 5).

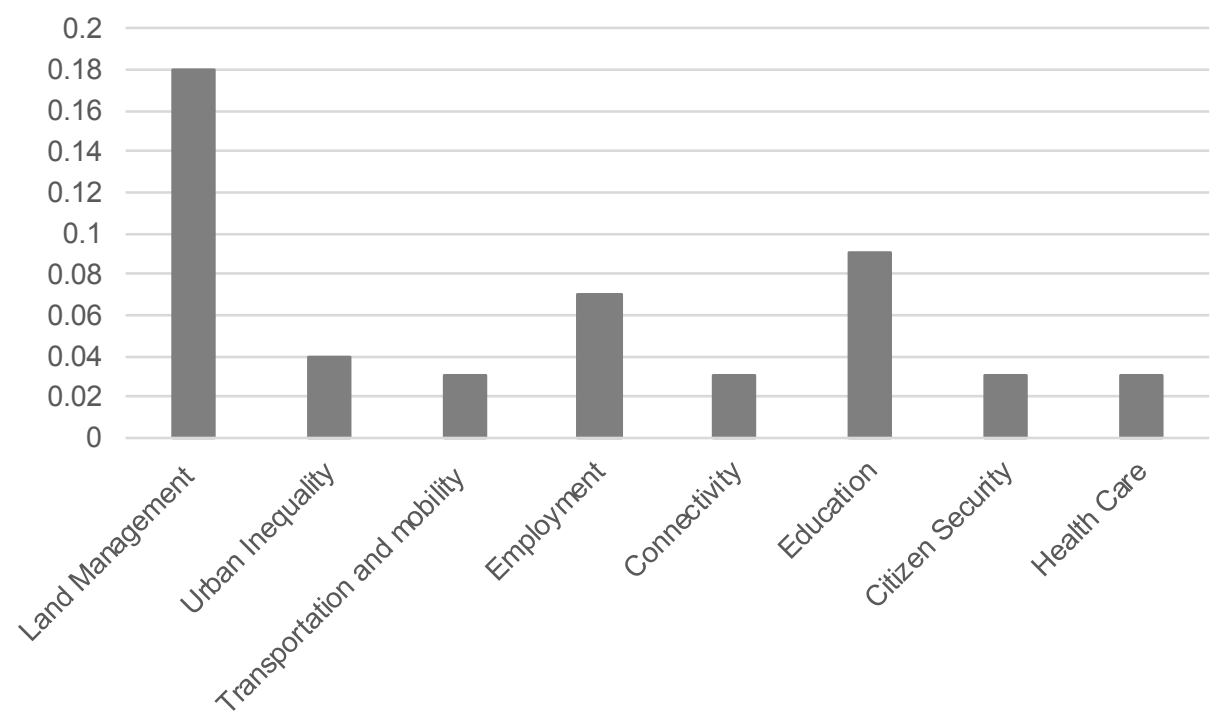

Figure 5 | Urban Sustainability: Weighting values of the topics considered for the index creation.

Source: Self elaboration based on previous studies (TOMADONI and ZULAICA, 2016; ZULAICA and TOMADONI, 2016).

The analysis of the distribution of sustainability indicators in the urban and peri-urban areas of Mar del Plata city seeks to gain insight into the territorial differences of these spaces. The spatial distribution of SI in the study area (Figure 6) indicates that the best conditions (very high sustainability, SI: 0.8050.897) are encountered, to a large extent, in the neighbourhoods comprising the urban area. 


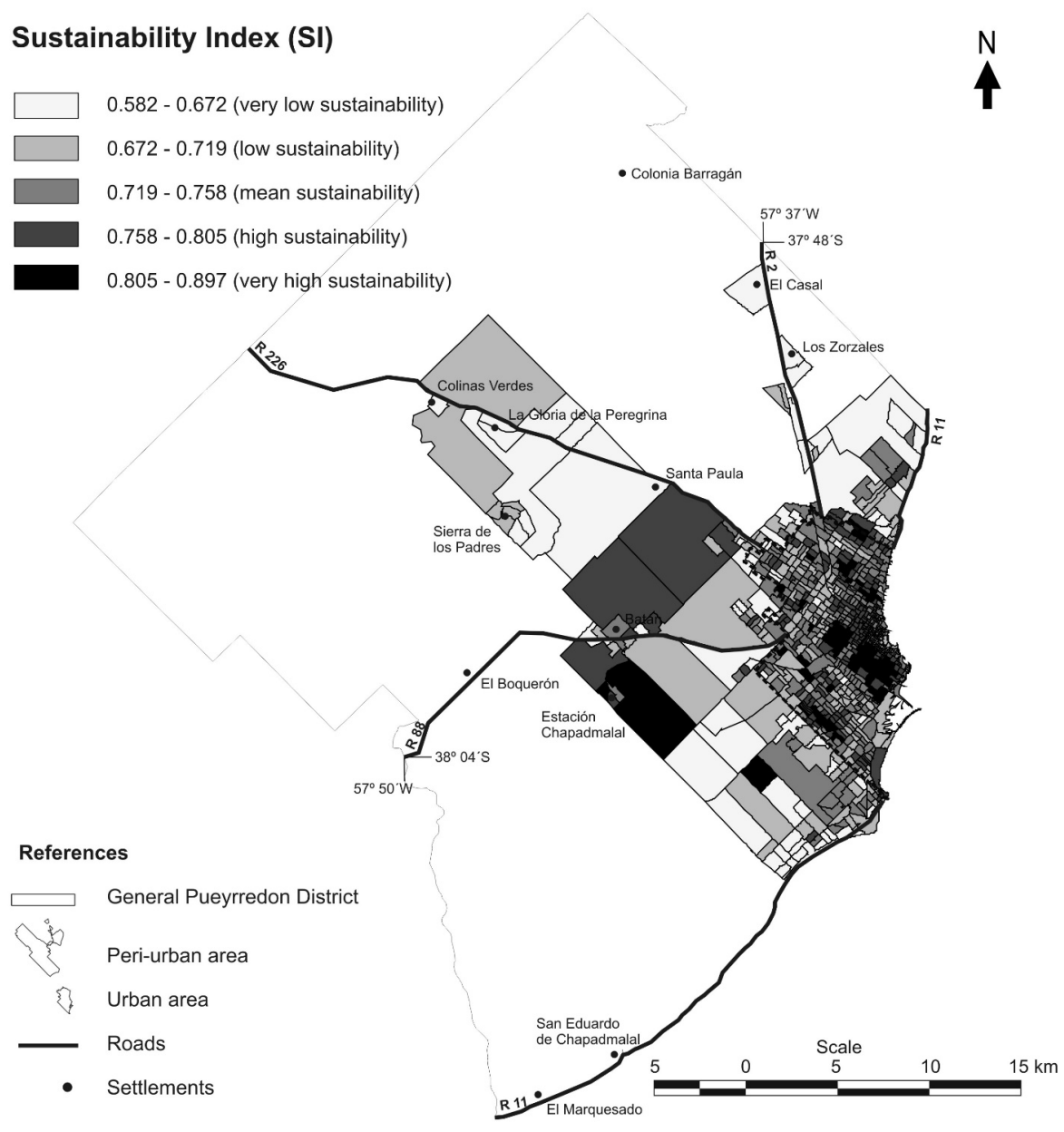

Figure 6 | Sustainability Index in the urban and peri-urban areas of Mar del Plata.

Source: Self elaboration from the index obtained.

At the other end of sustainability (very low sustainability, SI: 0.582-0.672) are mainly peri-urban areas where rural characteristics predominate and slums proliferate.

High (SI: 0.758-0.805) and mean (SI: 0.719-0.758) sustainability characteristics predominate in the urban area, while low sustainability values (SI: 0.672-0.719) prevail in the peri-urban area, except in sectors of Batán and rural areas close to this town and on Ruta Nacional 226 [route].

The comparison of the results independently extracted for each dimension through the Environmental Sustainability Index (ESI) and the Urban Sustainability Index (USI) reveal that environmental sustainability generally reaches higher values in the urban than in the peri-urban areas. In the latter, the southern coastal sector and the areas in which gated communities are located should be highlighted. By contrast, the analysis of urban sustainability reveals more favourable conditions in important zones of the periurban area with respect to its indicators.

The difference calculated between the ESI and USI values for each census radius, allowed to build a thematic map (Figure 7) that shows the contrasts between both dimensions. The map reveals that, in the peri-urban area, the index values of the urban dimension far supersede the estimates for the environmental dimension. The opposite situation is noticed in the urban, central and coastal areas and to the south of the peri-urban area, where the Sierra de los Padres stands out. This locality has shown important dynamism in recent years and is mainly occupied by medium- and high-income residents motivated by the beautiful scenery of the ranges bordered by intensive cropping, who look for comfort and tranquillity away from the hustle and bustle of the of the city (ZULAICA and CELEMíN, 2014). 
Differences between the ESI and USI

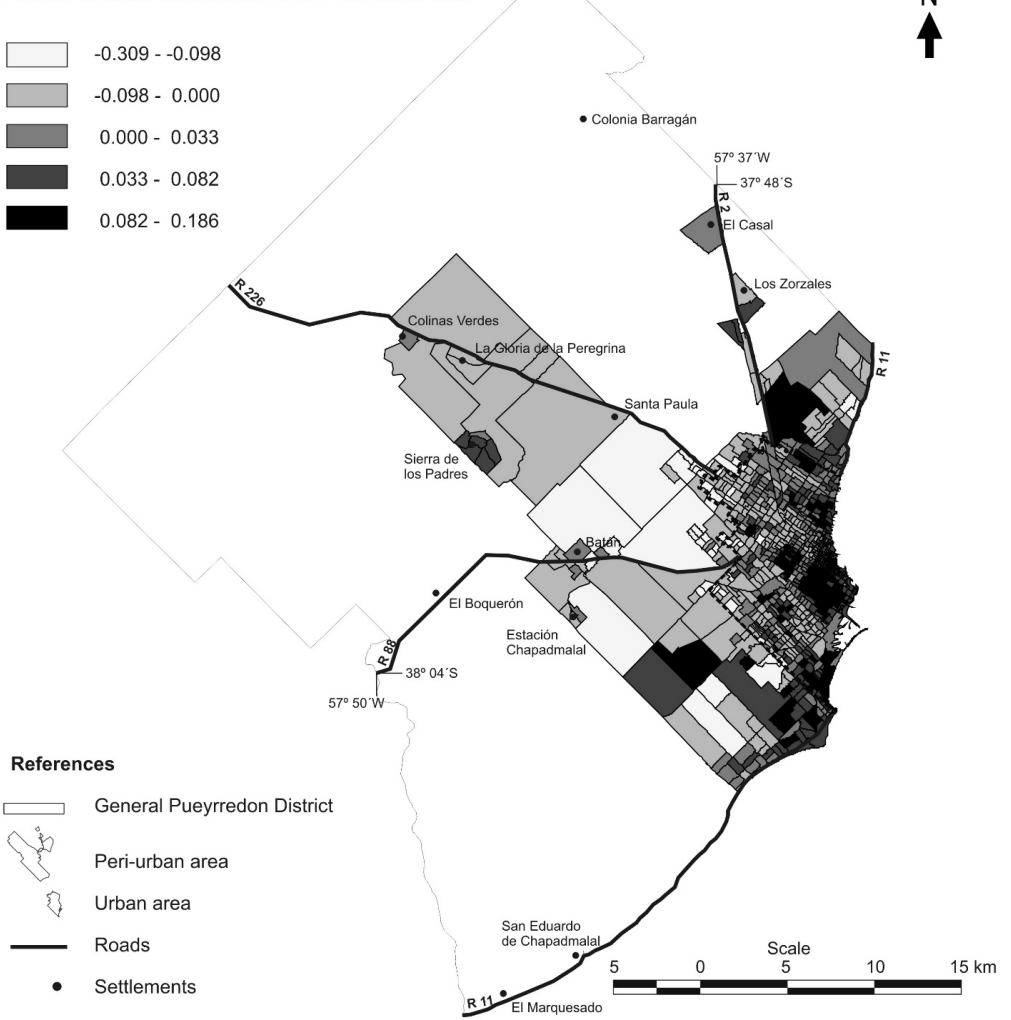

Figure 7 | Environmental Sustainability and Urban Sustainability Indices: Differences between the urban and peri-urban areas of Mar del Plata.

Source: Self elaboration from the indices obtained.

The negative differences between ESI and USI gave the opportunity to outline the neighbourhoods in which informal settlements are located, as determined by the vulnerability to natural disasters topic within the environmental dimension of sustainability.

The disparities in the values obtained are more significant in the environmental dimension as compared to the urban dimension; while, in both dimensions, the peri-urban area exhibits greater dispersion in the values obtained. This is no accident, since the peri-urban area constitutes a complex urban-rural interface (ALLEN, 2003; DI PACE, 2004) in a transitional situation and in constant transformation. The standard deviations of the indices according to urban, peri-urban and total areas are provided in Figure 8.

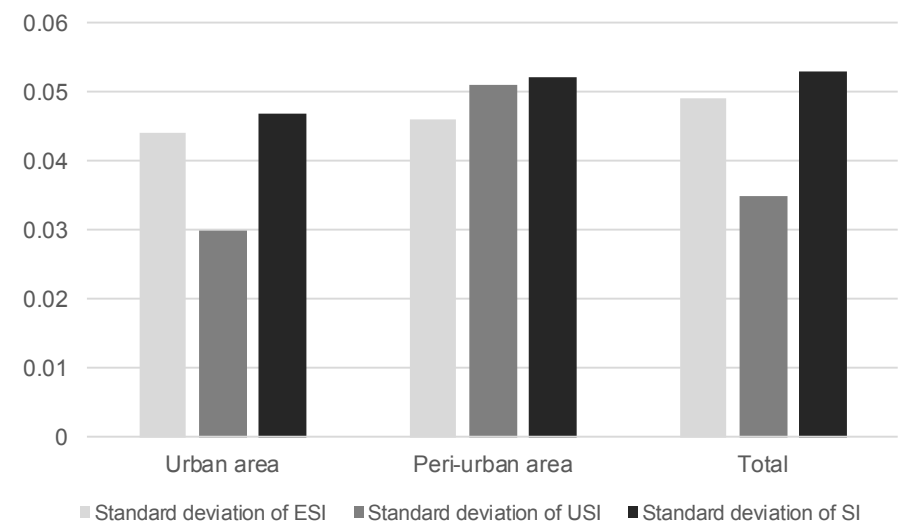

Figure 8 | Standard deviations of ESI, USI, and SI values for the urban and peri-urban areas of Mar del Plata city, and total. 


\subsection{INCIDENCE OF TOPICS IN THE SUSTAINABILITY INDEX AND ITS DIMENSIONS}

The analysis of the topics incidence in the Sustainability Index provides some explanatory elements regarding the spatial distribution of the values obtained. As far as environmental sustainability is concerned, the topics of energy and sanitation and drainage define, to a greater extent, the favourable and unfavourable situations of ESI.

This can be corroborated by applying the linear correlation coefficient (Pearson's r), which reaches 0.597 for energy and 0.572 for sanitation and drainage. In both cases, the aforementioned coefficient shows a mean positive correlation.

When the correlation coefficient is separately applied to the urban and peri-urban areas, maximum values are verified in the urban area $(r: 0.729)$, corresponding to noise pollution and air quality, which negatively affect the environmental sustainability of the city. In both cases, the percentage of the radius surface located less than $300 \mathrm{~m}$ away from the source of air or noise pollution exceeds $70 \%$ in the urban area, while in the peri-urban area it does not reach $40 \%$.

According to Municipio de General Pueyrredon (2013), as regards electric energy and gas supply indicators, the quality and coverage of the services are adequate. However, seasonal demand has a negative impact on services provision as they are covered by costly and inefficient generating units that produce high levels of greenhouse gas emissions (ZULAICA and TOMADONI, 2015). In the area under study, only the network gas supply indicator is analysed because, in the case of electric power, no data are available to make distinctions among the spatial units studied and, in general, the limitations displayed are not relevant.

By contrast, the availability of gas supply differs significantly within the peri-urban area, and its provision facilitates the development of domestic activities. The average values in the peri-urban area reveal that only $41.6 \%$ of households have access to gas, thereby exhibiting a sharp contrast with the urban area, where values reach $91.2 \%$. Despite the increase in the percentage of households with gas network supply in the city in recent years, there is an unmet demand that calls for new and necessary investments for infrastructure development (MAR DEL PLATA ENTRE TODOS INITIATIVE 2016).

The indicators related to sanitation and drainage considered in this work were: percentage of households with a home connection to the sewerage services and percentage of households with sanitary installations with water discharge. The latter did not present significant variations when the urban and peri-urban areas were compared, reaching average values of $98.4 \%$ and $88.4 \%$, respectively.

According to the information obtained from the 2015 Permanent Household Survey, $90.3 \%$ of permanent homes and $88.5 \%$ of the estimated population in the Mar del Plata-Batán cluster have access to sewerage services. Even though coverage is generally extensive, differentiations within the city reveal contrasting situations. According to the indicators analysed, the percentage of households with sewerage services in the urban area reaches an average value of $95.9 \%$, while in the peri-urban area it accounts for $20.4 \%$.

As regards the urban dimension of sustainability, the topic of land management/land use is the one with the greatest incidence in USI distribution. The linear correlation coefficient reaches 0.780 , showing a high positive correlation. Considering only the peri-urban census radii, the $r$ coefficient reaches a value very close to 1 ( $r$ : 0.902).

This topic includes housing indicators. It should be noted that the subsistence, identification and insertion needs of social groups, i.e., social sustainability, are affected by the conditions of houses built with precarious materials, without adequate access to health services, privacy or physical accessibility, among other issues. Within the land management/land use topic, the composite indicator with the highest incidence is the one made up of the percentage of households with severe overcrowding (more than 3 persons per room) and the percentage of households without a refrigerator. 
Households with severe overcrowding are located mainly in the peri-urban area (4.4\%), reaching an average of $1.2 \%$ in the urban area and of $1.9 \%$ in total. In many sectors, the critical values of this indicator are associated with the proliferation of slums, which manifest severe social conflicts and problems with the land tenure regime (state-owned or private land), which intensified after of the 2001 crisis (ZULAICA and CELEMÍN, 2014).

The availability of refrigerators is of vital importance to ensure food security. Proper food preservation prevents disease proliferation; and so, refrigerators are considered a necessary appliance to guarantee life quality (INSTITUTO NACIONAL DE ESTADÍSTICAS Y CENSOS, 2012). The percentage of households without refrigerators reached $2.0 \%$, showing differences between urban $(1.5 \%)$ and peri-urban areas (4.0\%).

With regard to the topic of land management/land use, it is worth mentioning that the community, together with the local political power, have made progress to implement a strategic planning process that has been in place for more than 15 years now and that has only been partially implemented in specific interventions (MAR DEL PLATA ENTRE TODOS INITIATIVE, 2016).

When the analysis considers the incidence of the topics of both dimensions in $\mathrm{SI}$, a mean positive correlation for education is obtained ( $r$ : 0.528). The analysis of the spatial distribution of this topic allows to establish the areas with the greatest difficulties in social inclusion, which negatively affects well-being and therefore urban sustainability. According to the categories defined by Sabuda (2008), many peri-urban sectors offer educational opportunities, but the family socio-cultural conditions prevent an adequate academic performance. Sometimes, difficult access to education is added to the foregoing.

Management strategies built around the topics related to the urban and environmental dimensions of SI, especially sanitation and drainage, energy, and land management/land use, which are the ones with the greatest impact on the index, should ensure equitable access to basic health care, adequate and safe housing and reliable energy sources. They should contribute to meeting the Sustainable Development Goals 6, 7 and 11 proposed by the UN for the next 15 years.

\subsection{SUSTAINABILITY IN THE URBAN AND PERI-URBAN AREAS OF MAR DEL PLATA: CONTRIBUTIONS FOR DISCUSSION}

The scattered growth of the cities has produced major transformations not only on the physical and morphological configuration of the territory, but also on the economic conditions, the social composition, and the social relations, to name a few aspects. This is evidenced by the different approaches that aim to define and categorize the peri-urban area and its dynamic processes (SALAZAR BURROWS, 2010).

According to Rees (2001), sustainable cities are not merely tied to the urban sphere but to the integrity of the external areas that depend directly or indirectly on them. Likewise, urbanization affects not only the local environment but also its surroundings through the exploitation of natural resources as the driving force of urban economy (MICHAEL et al., 2014). This generates and accentuates processes of socio-environmental vulnerability.

The comparative analysis of sustainability between urban and peri-urban areas of Mar del Plata poses challenges primarily associated with data availability at relevant analysis scales, especially in urbanrural transition zones. The dynamism of these zones, induced by endogenous and exogenous processes, leads to constant variations in their components and configuration. As a consequence, sustainability varies; and its estimation through indicators is key to visualizing and measuring progress and setbacks in the light of SDGs. 


\section{FINAL CONSIDERATIONS}

The development of indicators has become a key task for local governments seeking to generate proposals that aim to achieve sustainable cities (MICHAEL et al. 2014). In this sense, sustainability indicators allow for a useful diagnosis to monitor the progress made in terms of previously defined sustainable development goals.

Indicators have become the most commonly accepted approach to assess sustainable development. At a local level, indicators are mainly used in the decision-making process to generate intervention proposals, thereby allowing to reverse the problems that affect sustainability. This is the basis of the $\mathrm{ESCl}$ program of the IDB.

As mentioned in previous studies, the indicators used in the construction of the indices were adjusted according to the information available and that could be processed in the analysis scale used. Each one of these aspects or topics determines different categories of ESI, USI and SI and allows to determine the extent up to which a spatial unit (radius census) approaches or moves away from the concept of sustainability within the universe considered.

The sustainability analysis of Mar del Plata city and its peri-urban area, conducted with an index integrated by different indicators, allows to assess some of the different aspects involved in the concept, and to carry out comparative studies with other areas. Moreover, the study contributes to deepen the analysis of these sustainability dimensions, placing emphasis on the internal differentiations based on data that represent the territory addressed.

Nonetheless, this work is not intended to contribute with new intervention strategies but to provide a diagnosis of the real situation so as to visualize the differences between the urban and peri-urban areas. Historically, the interventions carried out to revert problems such as those comprised in the indicators, have taken place mainly in urban areas leaving the peri-urban zones underrepresented in the diagnoses carried out within the ESCl framework. This is the basis of the analysis developed in this study.

As a consequence, this work aims to contribute to the diagnosis of sustainability, identifying areas in need of specific improvement. In this sense, it is important to highlight that the most favourable $\mathrm{SI}$ values $(0.805-0.897)$ are generally found in the urban area, while the most critical ones $(0.582-0.672)$ are identified in the peri-urban area, mainly in those sectors where rural activities are developed and slums are located.

Beyond the methodological strategies employed, it is difficult to represent the inherent complexity of the topics involved in the concept of sustainability. Regarding limitations, it should be mentioned that oftentimes the lack of information prevents a deep exploration, especially into the analysis of causal relationships. In addition, we face the challenge of consolidating the theoretical and conceptual frameworks, delving deeper into their transferability and the possibility of establishing comparisons. The new questions posed inspire us to continue our research towards sustainability and its inclusion in the political agenda.

The need for an in-depth analysis of the spatial differentiations found in the different dimensions of sustainability in Latin American cities, leaves us with the challenge to build more sustainable places for present and future generations. 


\section{REFERENCES}

AGOL, D.; LATAWIEC, A.E.; STRASSBURG, B.B.N. Evaluating impacts of development and conservation projects using sustainability indicators: opportunities and challenges. Environ. Impact Assess. Rev., n. 48, p. 1-9, 2014.

ALLEN, A. La interfase periurbana como escenario de cambio y acción hacia la sustentabilidad del desarrollo. Cuadernos del Cendes, v. 20, n. 53, p. 7-21, 2003.

BONNEFOY, J.C.; ARMIJO, M. Indicadores de desempeño en el sector público. Santiago de Chile, Instituto Latinoamericano y del Caribe de Planificación Económica y Social (ILPES), CEPAL, Naciones Unidas, 2005.

BRAULIO-GONZALO, M.; BOVEA, M.D.; RUÁ, M.J. Sustainability on the urban scale: Proposal of a structure of indicators for the Spanish context. Environmental Impact Assessment Review, n. 53, p. 16-30, 2015.

BUZAI, G., 2003. Mapas sociales urbanos. Buenos Aires: Lugar Editorial.

DI PACE, M. (director). Ecología de la ciudad. Buenos Aires: Editorial Prometeo-UNGS, 2004.

FERRARO, R.; GAREIS, C.; ZULAICA, L. Aportes para la estimación de la Huella de Carbono en los grandes asentamientos urbanos de Argentina. Cuadernos de Geografía, v. 22, n, 2, p. 87-106, 2013.

GALLOPIN, G., 2003. Sostenibilidad y Desarrollo Sostenible: un enfoque sistémico. Santiago de Chile: CEPAL, Serie Medio Ambiente, División de Desarrollo Sostenible y Asentamientos Humanos.

GAREIS, M.C.; FERRARO, R. Estimación de la subhuella de ambiente construido del partido General Pueyrredon, Argentina. Cuaderno Urbano, 19 (19), 57-72, 2015.

GUIMARÃES, R. Tierra de sombras: desafíos de la sustentabilidad y del desarrollo territorial y local ante la globalización corporativa, № 67. Santiago de Chile: CEPAL, Serie Medio Ambiente, División de Desarrollo Sostenible y Asentamientos Humanos, 2003.

HOLDEN, M. Sustainability indicator systems within urban governance: Usability analysis of sustainability indicator systems as boundary objects. Ecological Indicators, n. 32, p. 89-96, 2013.

INSTITUTO NACIONAL DE ESTADÍSTICAS Y CENSOS, 2010. Censo Nacional de Población, Hogares y Viviendas. Buenos Aires: Instituto Nacional de Estadísticas y Censos, 2010.

INSTITUTO NACIONAL DE ESTADÍSTICAS Y CENSOS, 2012. Censo Nacional de Población, Hogares y Viviendas 2010: Censo del Bicentenario. Resultados definitivos, Serie B № 2 - 1a edición. Buenos Aires: Instituto Nacional de Estadísticas y Censos, 2012.

INTER-AMERICAN DEVELOPMENT BANK. Guía metodológica; Iniciativa Ciudades Emergentes y Sostenibles (segunda edición). Banco Interamericano de Desarrollo, 2014.

INTER-AMERICAN DEVELOPMENT BANK. Documento de Enfoque: Evaluación de la Iniciativa Ciudades Emergentes y Sostenibles. Washington: Banco Interamericano de Desarrollo, 2016.

KWATRA, S.; KUMAR, A.; SHARMA, P.; et al. Benchmarking sustainability using indicators: An Indian case study. Ecological Indicators, n. 61, p. 928-940, 2016.

MAR DEL PLATA ENTRE TODOS INITIATIVE. Primer Informe de Monitoreo Ciudadano: saber para entender, entender para actuar. Mar del Plata: Red de Monitoreo Ciudadano, 2016.

MICHAEL, F.L.; ZAINON NOOR, Z.; FIGUEROA, M.J. Review of urban sustainability indicators assessment e Case study between Asian countries. Habitat International, n. 44, p. 491-500, 2014.

MORI, K.; CHRISTODOULOU, A. Review of sustainability indices and indicators: Towards a new City Sustainability Index (CSI). Environmental Impact Assessment Review, v. 32, n. 94-106, 2012.

MUNICIPIO DE GENERAL PUEYRREDON. Plan de acción, Mar del Plata Sostenible. Mar del Plata: Municipio de General Pueyrredon y Banco Interamericano de Desarrollo, 2013. 
NATENZON, C. Riesgo, vulnerabilidad e incertidumbre. Desastres por inundaciones en Argentina. Seminario sobre Problemas ambientales e vulnerabilidade, Abordagens integradoras para o campo da Saude Publica. Rio de Janeiro: Ministerio de la Salud, 1998.

PEARSON, K. Notes on regression and inheritance in the case of two parents. Proceedings of the Royal Society of London, n. 58, v. 240-242, 1895.

PÉREZ MORALES, A.; NAVARRO heRVÁS, F.; ÁlVAREZ ROGE, Y. Propuesta metodológica para la evaluación de la vulnerabilidad social en poblaciones afectadas por el peligro de inundación: el caso de Águilas (Murcia, sureste ibérico). Documents d’ Anàlisi Geogràfica, v. 62, n. 1, p. 133-159, 2016.

REBORATTI, C. Ambiente y sociedad: conceptos y relaciones. Buenos Aires: Editorial Planeta Argentina, 2000.

REED, M.S.; FRASER, E.D.; DOUGILL, A.J., 2006. An adaptive learning process for developing and applying sustainability indicators with local communities. Ecol. Econ., v. 59, n. 4, p. 406-418, 2006.

REES, W.E. The conundrum of urban sustainability. In D. Devuyst, L. Hens, W. De Lannoy (editors) How Green Is the City? Sustainability Assessment and the Management of Urban Environments (p. 37-42). New York: Columbia University Press, 2001.

ROCCA, M. J.; LANCIONI, A.; SGROI, A.; CAROL, I.; RÍOS, L. Sustentabilidad territorial e instrumentos de regulación del periurbano. XI Simposio de la Asociación Internacional de Planificación Urbana y Ambiente. La Plata: Facultad de Arquitectura y Urbanismo, Universidad Nacional de La Plata, 2014.

RODRÍGUEZ IGLESIAS, G.; BAZÁN, A. El periurbano marplatense: Una propuesta de delimitación. X Seminario de RedMuni: nuevo rol del Estado, nuevo rol de los Municipios. Ciudad Autónoma de Buenos Aires: Dirección de Investigaciones del Instituto Nacional de la Administración Pública (INAP), 2009.

SABUDA, F. Diferenciación socio-cultural de los hogares. Aportes para el análisis territorial de la vulnerabilidad educativa en el Partido de General Pueyrredon. In P. Lucero (Ed.), Territorio y Calidad de Vida, una mirada desde la Geografía Local (p. 141-176). Mar del Plata: Eudem, Universidad Nacional de Mar del Plata, 2008.

SALAZAR BURROWS, A. Transformaciones socio-territoriales en la periferia metropolitana: la ciudad periurbana, estrategias locales y gobernanza en Santiago de Chile. XI Coloquio Internacional de Geocrítica "La planificación territorial y el urbanismo desde el diálogo y la participación”. Ciudad Autónoma de Buenos Aires: Universidad de Buenos Aires, 2010.

SCHUSCHNY, A.; SOTO, H. Guía metodológica, diseño de indicadores compuestos de desarrollo sostenible. Santiago de Chile: CEPAL, Naciones Unidas, 2009.

TOMADONI, M.; ZULAICA, L.; CALDERÓN, G. Sostenibilidad urbana en la zona de transición urbano-rural de Mar del Plata. Revista i+a, investigación + acción, n. 16, p. 71-90, 2014.

TOMADONI, M.; ZULAICA, L. Evaluación de la sostenibilidad urbana y ambiental en Mar del Plata y su periurbano, mediante indicadores. Primeras Jornadas de Hábitat y Ambiente. Mar del Plata: Instituto del Hábitat y del Ambiente, FAUD, UNMdP, 2016.

TRAN, L. An interactive method to select a set of sustainable urban development indicators. Ecological Indicators, n. 61, p. 418-427, 2016.

UNITED NATIONS. Estado de las ciudades de América Latina y el Caribe: Rumbo a una nueva transición urbana. Río de Janeiro: Programa de las Naciones Unidas para los Asentamientos Humanos, 2012.

WORLD COMMISSION ON ENVIRONMENT AND DEVELOPMENT. Our Common Future. The World Commission on Environment and Development. Oxford: Oxford University Press, 1987.

WOOD, S.L.R.; JONES, S.K.; JOHNSON, J.A.; et al. Distilling the role of ecosystem services in the Sustainable Development Goals. Ecosystem Services, n. 29, p. 70-82, 2018.

ZHOU, J.; SHEN, L.; SONG, X.; ZHANG, X. SELECTION and modeling sustainable urbanization indicators: Aresponsibility-based method. Ecological Indicators, n. 56, p. 87-95, 2015. 
ZULAICA, L.; CELEMÍN, J. P. Condiciones de habitabilidad y crecimiento poblacional en el periurbano de la ciudad de Mar del Plata, Argentina. Revista Espaço e Geografia, v. 17, n. 1, p. 281-321, 2014.

ZULAICA, L.; FERRARO, R. Evolution of Habitability Conditions in Mar del Plata Peri-urban Area (1991, 2001, 2011). In G. Tonon (Ed.), Indicators of Quality of Life in Latin America, Social Indicators Research Series, Vol. 62, (pp. 219-233). Heilderberg, Dordrecht, New York, London: Springer, 2016.

ZULAICA, L.; TOMADONI, M., 2015. Indicadores de sostenibilidad ambiental en el periurbano de la ciudad de Mar del Plata, Argentina. Anales de Geografía de la Universidad Complutense, v. 35, n. 2, p. 195-216, 2015.

ZULAICA, L.; TOMADONI, M. Evaluación de la sostenibilidad ambiental en el área urbana de Mar del Plata y su periurbano, mediante indicadores. IV Jornadas Nacionales de Investigación en Geografía Argentina. Tandil: Centro de Investigaciones Geográficas, FCH, UNCPBA, 2016. 